\title{
The economic impact of irrigation agriculture: Methodological aspects and an empirical application
}

\section{J F Kirsten and J van Zyl}

\section{INTRODUCTION}

The economic viability of water projects is usually determined by means of benefit-cost analysis. Although this provides a good conceptual framework for the economic evaluation of projects, it is a one-dimensional criterion which concentrates on increasing national income through increased efficiency and productivity. Distribution and equity considerations are thus ignored and are secondary to the efficiency objective (Martin, 1979:107; Carruthers, 1973:25: Young, 1978:259). For this reason the American Water Resources Council has identified four criteria whereby projects should be evaluated (see, among others, Lewis et al. 1973 and Eisel et al, 1982), namely national economic development, environmental conservation, regional development and social welfare. By accepting these principles, and specifically that of regional development, a new sentiment originated towards water projects as a method for promoting regional development. However, economists have traditionally been sceptical about the possible regional economic benefits of water and water projects (Butcher, 1974: 60).

Several studies have tested the hypothesis that water resource development results in regional economic growth (Fullerton et al, 1975; Cicchetu" et al 1975; Back 1969; Bell et al, 1982 and Lewis et al 1973; Young. 1978; Howe, 1968; Cox et al, 1971; Gardner \& Huffaker, 1988; Powell et al, 1985 and Whlttlesey et al, 1978). From these studies it is clear that there is no definite empirical evidence for the existence of secondary or economic growth benefits of irrigation development in a national context. There is also, however, no evidence to the contrary as far as regional economic growth is concerned. It can thus be concluded that irrigation development can potentially influence regional income, production, employment and income distribution.

A question that is frequently asked in this debate is: Should the indirect growth effects of water projects be included in benefit-cost calculations? The answer depends to a large extent on the existence of surplus capacity in the economy (Castle et al, 1981: 53). It may, however, happen that the regional secondary or economic growth benefits are cancelled by costs elsewhere in the economy (Stoevener \& Kraynick, 1979: 1115; Oosthuizen et al. 1987: 2.6). 
This article considers the contribution of irrigation development to the economic growth of a specific region. The indirect benefits in regional perspective are therefore of particular importance. The existence of such benefits is also more obvious on regional level than on national level. More specifically, the article considers the regional economic impact of irrigation development by means of a case, study.

In the next section theoretical aspects of the impact of irrigation development are discussed. This is followed by a brief overview of methodological alternatives for the determination of the impact of irrigation development with special reference to input-output analysis. Some empirical applications are also referred to. A case study of the south-western Orange Free State is used to test some of the theoretical principles that have been put forward. First the deduction of the regional input-output table is discussed. This is followed by the determination of the economic Impact of irrigation agriculture in the south-western Orange Free State and a discussion of the major findings.

\section{THE IMPACT OF IRRIGATION DEVELOPMENT - A THEORETICAL PERSPECTIVE}

The development and utilization of water resources in agriculture through irrigation development creates an economic atmosphere that has direct and indirect benefits for the local economy. Examples of these benefits are the economic, social, demographic, public services and fiscal impacts (Leistritz \& Murdock, 1981). In this article the economic impact is discussed in more detail. This comprises both the direct Impact on agricultural income and the indirect impact on other sectors because of the change in agricultural income. The accent falls further on the current Impact (Lamphear \& Rousler, 1974:2) and does not take the investment Impact into account.

\subsection{Direct Impact}

The direct impact of irrigation development is the increase in agricultural production above that which is normally produced under dryland conditions. In the case of the current impact the direct impact refers to the total production under irrigation with its related direct Increase in gross farming receipts and expenditure. The magnitude of the direct impact of irrigation development is given by the difference in yield between dryland and irrigation production.

Identification and measurement of direct benefits of irrigation development are relatively easy. There is also very little to say against the Inclusion of these impacts when considering the Impact of irrigation development.

\subsection{Indirect impact}

In the case of a private irrigation development, the indirect impact is of little or secondary importance to the developer. However, it plays an important role in public projects with respect to evaluation and finance. Questions normally asked in this regard are: What is the importance of the indirect impact and where is it concentrated? Bell. Hazell \& Slade (1982:3 - 4) are of the opinion that the 
indirect impact of an agricultural project is considerable and that it is centered on the local economy.

Apart from the direct impact of higher yields, sales and expenditure on farms. the linkages between different sectors and industries in the economy cause a multiplier effect in reaction to the direct impact. Each sector in the regional economy reacts individually to the increased production and activity in agriculture, resulting in an increase in general economic activity in the area. This increase in economic activity is seen as one of the most important indirect benefits of irrigation development (Long, 1980:1002). The motivation for the existence of indirect multiplier effects on the regional level lies in the interdependence of the regional economy and the existence of linkages. Bell \& Hazell (1980:75) put it as follows:

Investment projects may generate substantial indirect effects or pecuniary external economies. These effects stem mainly from production linkages...

These production linkages can be either backwards or forwards. Backward linkages refer to the linkage of irrigation agriculture with the input and resource suppliers, while forward linkages bear on the linkages with marketing and processing industries.

Apart from these production linkages there are also consumption linkages because of the higher income from irrigation agriculture that results in an increase in final demand (Bell \& Hazell, 1980:75). Irrigation development leads to higher production, which implies increased consumption of inputs, as well as higher production receipts for the farmer. Given the interdependence of the economy, this higher income and demand for inputs stimulates a multiplier effect that eventually results in an increase in economic activity.

\section{METHODOLOGICAL ALTERNATIVES FOR DETERMINING THE IMPACT OF IRRIGATION DEVELOPMENT}

The measurement of the impact of irrigation development consists of the empirical determination of the ratio between cause and effect, and contains two basic elements (Pleeter, 1980: 1):

- a valuation of the exogenous stimulus (eg irrigation development) that serves as direct impact

- a model of the regional economy to calculate the indirect effects.

The relationship between cause and effect can be described on the basis of multipliers or total value added (Powell et al. 1985:5). The multiplier concept (Kahn, 1931) is of importance in impact studies. It can be described as a unit of autonomous investment that initially leads to an increase in income, that again generates successive rounds of consumer expenditure and income. This process continues until an equilibrium is reached. The ratio between the initial expenditure and the total effect on the economy is the multiplier effect or the impact of investment in the specific sector on the rest of the economy (O'Connor \& Henry, 1975: 41). 
The selection of a method to measure the impact of irrigation development thus entails finding the most suitable method for calculating multipliers with which the indirect effects on the economy can be determined, given restrictions such as data. Different models that are frequently used for empirically measuring the impact of irrigation development are now briefly discussed.

\subsection{The economic base theory}

Tiebout (1962) developed the economic base theory from Keynesian macro theory. The theory is thus viewed as a simpler version of Keynesian demand theory (Edwards, 1981: 198). According to the economic base theory, economic activities in a region can be divided into two categories, namely activities that produce goods and services for export markets and activities that produce goods and services for the local market. Activities are thus divided into export or basic activities and non-basic activities. The economic growth of a region is viewed as a function of the magnitude of the region's exports or basic activities. Economic base theory thus accentuates the openness of the regional economy (Richardson, 1973: 11). If the exogenous demand for goods and services from the basic sectors increases, the basic sectors will expand which will result in growth in the non-basic sectors (Leistritz \& Murdock, 1981: 21).

In this model the magnitude of economic activity in a region must be divided into basic and non-basic activities in order to calculate the basic multiplier (Pleeter. 1980:13: Mazuera, 1969:28). Employment, income, sales and value added can be used as criteria In this regard (Fourie, 1977: 39). Indirect identification techniques, such as the assumption method, location coefficients, the minimum specification method and the primary data method, are described in the literature for the division of activities (Leistritz \& Murdock, 1981: 29-33).

The economic base model is simple to use, but this places restrictions on its applicability (Mentzas et al, 1987: 153). It provides only limited information on the economic impact and is dependent on the accuracy of the economic base multiplier. The model concentrates on changes in export demand and ignores internal changes within the region. It can thus only be used with certain qualifications and is therefore not suitable for evaluating the economic impact of irrigation development in a regional context.

\subsection{Input-output models}

Economic base theory is viewed as a forerunner and special case of the inputoutput model (Fullerton et al, 1975:36; Edwards, 1981:198; Romanoff, 1974). However, input-output models do take inter-sectoral transactions into account to give a more detailed impact result. This characteristic has resulted in the widespread use of specific regional input-output models in impact analyses (Mentzas et al, 1987: 153).

Input-output models are based on the interdependence of a region's industries and households. The regional economy is divided into different sectors where the interdependence is shown in a quantitative manner by means of a transaction table. Input-output tables are thus a mathematical 
representation of the (regional) economy from which multiplier effects can be calculated (Mules, 1983: 13).

An important restriction in the application of the input-output technique is that reliable data can only be obtained with effort and therefore at a cost. It does, however, provide a detailed impact analysis and is fairly flexible (Richardson, 1973:41). Schaffer (1980) is of the opinion that input-output models are ideally suited to impact analyses. Mules (1983) shares this sentiment and also shows that it can be used with great success when determining the impact of changes in agriculture, eg irrigation development, on non-agricultural sectors.

\subsection{Econometric models}

A recent development in regional analysis is the growing interest in econometric models. This involves sets of multiple equations that describe the structure of the local economy and predict variables such as income, employment and production (Pleeter, 1980:18). The models are based on time-series data. Regression analysis is used to determine relationships between variables (Letstritz \& Murdock, 1981: 40).

Econometric models are based on fewer assumptions than the previous models discussed. The paucity of reliable regional data, however, frequently means that this method cannot be used. Although econometric models based on the general equilibrium theory have the potential to facilitate impact analyses in the same way as input-output models (Powell et al, 1985:6), this shortcoming makes it less attractive when determining the economic impact of irrigation schemes where the lack of reliable time-series data is frequently a common feature. Statistical problems such as auto-correlation and multicollinearity may also influence the magnitude of coefficients and thus complicate the application of this method even further.

\subsection{Mathematical programming}

Mathematical programming involves a technique whereby an objective function is maximized given certain restrictions. These methods, of which linear and quadratic programming are the best known, can also be used in impact analyses (Powell et al, 1985:6). The development of sectoral and regional linear programming models is of special importance (Hazell \& Norton, 1986). The advantage of these methods lies in the ex-ante measuring of impacts rather than the ex-post determination thereof. They can also be combined with input-output analyses to illustrate the economic impact of an economic change on the rest of the economy (Hewings. 1985: Hewings \& Jensen. 1986).

Mathematical programming models have a further advantage in that they can be constructed without detailed time-series data. In this respect the data requirements are similar to that of input-output tables. The objective function which has to be maximized does, however, restrict its applicability in impact analyses. Powell et al (1985:6) therefore question the reliability and relevance of mathematical programming in impact analyses.

\subsection{Comparison of regions}

This method consists of the comparison of two regions that are geographically, economically, socially and politically comparable. The only difference is that in 
one region irrigation agriculture is practised, while in the other dryland and/or livestock farming is practised. A critical assumption of this approach is that irrigation is also possible in the other region (McCullick, 1970: 6). It also assumes that the benefits stemming from irrigation are solely responsible for the differences between the two regions. Various statistics can be used to quantify the impact of irrigation development (Olivier, 1972: 101).

The lack of a suitable and comparable area where no irrigation is practised, as well as the paucity of reliable regional data on the different parameters, frequently renders this method impractical and impracticable. These problems are compounded by the stringent and often far-fetched assumption that irrigation development is solely responsible for differences between the regions.

\subsection{Empirical applications and case studies concerning the economic impact of irrigation development}

Various empirical economic impact studies in irrigation agriculture using the different methods discussed above are cited in the literature. Powell et al (1985) used input-output tables that were compiled by means of the GRIT-technique to quantify the economic impact of irrigation in New South Wales in Australia, while Underwood \& McLellan (1984) determined the value of irrigation development in the Canadian province of Alberta using the same technique. Input-output analyses were also used by McCullick (1970) to determine the impact of irrigation in Kansas, by Lamphear \& Rousler (1984) in Nebraska and by Fullerton et al (1975) in Colorado.

The comparison of regions method was used by Walker et al (1966) to measure the economic impact of irrigation development in Columbia over time while Brown (1981) used an econometric model for the same purpose in Missouri. Bell \& Hazell (1980) used mathematical programming to determine the indirect effects of an irrigation project in Malaysia. Economic base theory and linear programming were used to determine the economic impact of irrigation agriculture in Oklahoma (Mazuera. 1969).

In South Africa only one study that attempted to quantify the economic and social impact of irrigation development, also with respect to indirect benefits. was found. Oosthuizen et al (1987) used economic base theory to study the development of the Vaalharts Irrigation Scheme. The study provides a good qualitative discussion, but does not succeed in determining the real magnitude of the total economic impact.

\section{A MODEL FOR MEASURING THE ECONOMIC IMPACT OP IRRIGATION DEVELOPMENT IN THE SOUTH-WESTERN ORANGE FREE STATE}

\subsection{Introduction}

Given the above, as well as the objective of effecting a more detailed economic impact analysis, input-output analysis was chosen to determine the economic impact of Irrigation development in the south-western Orange Free State.

The south-western Orange Free State is, for the purpose of this study, defined as consisting of the magisterial districts of Fauresmith, Koffiefontein, Jacobs- 
dal, Jagersfontein and Philippolis. This area includes the following irrigation areas and schemes: Van der Kloof beneath the P K le Roux dam, the 'Rietriviernedersetting' and the farmers alongside the Riet River beneath the Kalkfontein dam, and the farmers alongside the lower Modder River. Table 1 provides an indication of the land utilization pattern, number of formers and number of businesses in the area.

\subsection{Construction of an input-output table for the south western Orange Free State}

The transaction table is the basic and most important table of the input-output system. A table of technical coefficients and interdependency coefficients can be obtained through mathematical manipulation of the transaction table (O'Connor \& Henry, 1975:6: McCullick, 1970: 17). Output multipliers, income multipliers and employment multipliers can be determined from these two tables (Richardson. 1972: 33). These multipliers provide criteria for measuring ecoomic activity in a given region.

Various methods can be used to compile the transaction table of the input-output table (Johns 4 Leat, 1987:244). Product-based methods, survey-based methods, non-survey methods and semi-survey methods are described by Hewings \& Jensen (1986: 307316). Non-survey methods can be subdivided into the location coefficient approach (Isserman, 1980; Morrison \& Smith, 1974: 8), the product balance approach (Roukens de Lange, 1985:7-8) and iterative procedures (Hewings \& Jensen, 1986). Semi-survey techniques comprise the GIS system (Schaffer, 1976). the GRIT technique (West et al. 1979: 1980: Powell et al, 1985:11) and the ASSET approach (Smith \& Jensen, 1984). In general the construction of the transaction table is a costly and time-consuming exercise, regardless of the method used.

For the purpose of this study, a variation of the commodity balance approach was used. This method was initially developed to compile input-output tables for the nine development regions of South Africa (Mohr \& Van Seventer, 1988), but is flexible enough to be applied to the subregional level The approach is described in more detail by Roukens de Lange (1985) and Mirrilees (1984).

Application of the above method on the subregional level, will, however, be accompanied by a reduction in accuracy. The results of this method were therefore complemented by additional primary and secondary data sources.

A list of all the enterprises active in the region was obtained by consulting the Orange Free State telephone directory. According to Bonner \& Vahle (1967) and Richardson (1972:91) this is a relatively easy and inexpensive way to compile such a list and the logical starting point. The necessary information was obtained by writing or by telephone, as well as from the population census and agricultural census (Central Statistical Services, 1987).

To increase the accuracy of the table, more accurate secondary data obtained from the 1985 agricultural census were used to replace the mechanically determined coefficients. The combination of survey and non-survey techniques to compile a regional input-output table very much resembles the GRIT technique applied by West et al (1979). 
Table 1 - Farming and business profile for the south-western Orange Free State, 1985

\begin{tabular}{|c|c|c|c|c|c|c|}
\hline \multirow{2}{*}{ Item } & \multicolumn{6}{|c|}{ District or area } \\
\hline & $\begin{array}{l}\text { Faure- } \\
\text { smith }\end{array}$ & $\begin{array}{l}\text { Jagers- } \\
\text { fontein }\end{array}$ & $\begin{array}{l}\text { Philip- } \\
\text { polis }\end{array}$ & $\begin{array}{c}\text { Jacobs- } \\
\text { dal }\end{array}$ & $\begin{array}{l}\text { Koffie- } \\
\text { fontein }\end{array}$ & $\begin{array}{c}\text { Outside } \\
\text { study } \\
\text { area }\end{array}$ \\
\hline Number of farmers & 205 & 40 & 107 & 189 & 31 & N/A \\
\hline \multicolumn{7}{|c|}{ Land utilization pattern (ha) } \\
\hline - Total area & 483862 & 128205 & 342657 & 260295 & 190624 & N/A \\
\hline \multicolumn{7}{|l|}{ - Irrigation: } \\
\hline Government & 4077 & 0 & 470 & 7626 & 1991 & N/A \\
\hline Private & 1511 & 365 & 655 & 123 & 227 & N/A \\
\hline - Dryland & 15111 & 0 & 0 & 10000 & 12000 & N/A \\
\hline - Veld & 463163 & 127840 & 341532 & 242546 & 176406 & N/A \\
\hline \multicolumn{7}{|c|}{ Type and number of businesses in area } \\
\hline - Co-ops & 3 & 1 & 1 & 2 & 1 & N/A \\
\hline - General dealer & 7 & 5 & 4 & 11 & 5 & N/A \\
\hline - Cafe & 3 & 5 & 3 & 3 & - & N/A \\
\hline - Dairy & - & 1 & - & - & 1 & N/A \\
\hline - Chemist & - & 2 & - & 2 & 1 & N/A \\
\hline - Retail: Clothes & 1 & 2 & 1 & - & 1 & N/A \\
\hline - Retail: Furniture & - & - & 1 & - & 1 & N/A \\
\hline - Garages & 3 & 1 & 3 & 4 & 3 & N/A \\
\hline - Tractors/implements & - & 1 & - & 1 & 2 & N/A \\
\hline - Hotel & 2 & - & 1 & 2 & 1 & N/A \\
\hline - Repairs and service & 1 & 2 & 1 & - & 1 & N/A \\
\hline - Petroleum & 1 & - & - & - & 3 & N/A \\
\hline \multicolumn{7}{|c|}{ Marketing of products by irrigation farmers within the area (\%) } \\
\hline - Wheat & 1.5 & 0.0 & 0,0 & 66.7 & 6.1 & 25.7 \\
\hline - Maize & 0.0 & 0,0 & 0.0 & 27,3 & 0.0 & 72.7 \\
\hline - Cotton & 0.0 & 0.0 & 0,0 & 80.0 & 0,0 & 19.2 \\
\hline - Potatoes & 23.1 & 0.0 & 0.0 & 0,0 & 0,0 & 76.9 \\
\hline - Vegetables & 0.0 & do & 0.0 & 1.0 & 2,0 & 97.0 \\
\hline - Grapes (wine) & 0.0 & 0.0 & 0,0 & 100.0 & 0,0 & 0,0 \\
\hline - Lucerne & 11.1 & 0,0 & 0,0 & 33.0 & 0.0 & 55.6 \\
\hline \multicolumn{7}{|c|}{ Purchasing of inputs and equipment by irrigation farmers (\%) } \\
\hline - Seed & 13,5 & 0,0 & 0.0 & 62.2 & 8,1 & 16.2 \\
\hline - Seed potatoes & 23,5 & 0.0 & 0.0 & 23,5 & 5.8 & 47.1 \\
\hline - Fertilizer & 11.4 & 0.0 & 0.0 & 64.5 & 8.9 & 15.2 \\
\hline - Packaging & 22.6 & 0.0 & 0.0 & 41,9 & 19.4 & 16.1 \\
\hline - Fuel & 5.1 & 0.0 & 0.0 & 50,0 & 10,2 & 34.6 \\
\hline - Chemicals & 6.7 & 0,0 & 0.0 & 62.2 & 8.1 & 23.0 \\
\hline - Tractors & 3.7 & 0,0 & 0.0 & 33.9 & 9,4 & 52,8 \\
\hline - Implements & 10.9 & 0,0 & 0,0 & 46.9 & 10,9 & 31,3 \\
\hline - Irrigation equipment & 18.5 & 0.0 & 0.0 & 38.5 & 3.1 & 40.0 \\
\hline - Parts & 10.4 & 0,0 & 0.0 & 55.8 & 3,9 & 29.9 \\
\hline
\end{tabular}


To determine the economic impact of irrigation agriculture it is, however, necessary to determine a separate set of multipliers for irrigation agriculture. It was thus also necessary to divide the agricultural sector into irrigation and the rest of agriculture.

This was done by using the method suggested by Powell et al (1985). In principle this entails the allotment of the total production value of irrigation agriculture to the thirteen endogenous sectors and four primary input sectors that were identified in the south-western Orange Free State. Total output was also allotted among the thirteen intermediary and five final demand columns. The column and row constructed for irrigation agriculture in this way were then deducted from the row and column for total agriculture. Two different sectors for agriculture, namely irrigation agriculture and the rest of agriculture, were thus constructed.

In order to construct the column and row for irrigation agriculture the area and crops under cultivation (irrigation) were determined first. Following Powel et al (1985), Booth et al (1981) and Anderson \& Manning (1983), enterprise budgets were compiled for all the major crops. Questionnaires were used to obtain other relevant information, namely where farmers buy Inputs and sell their products.

\subsection{Summary}

This costly and relatively complicated procedure resulted in the deduction of an input-output table for the south-western Orange Free State with 1985 as base year. In the final input-output table for the south-western Orange Free State agriculture is represented by two sectors, one for irrigation agriculture and the other for the rest of agriculture, mainly livestock farming. This final input-output table, or transaction table, appears In Table 2.

Table 2 provides a picture of the linkages between irrigation agriculture and the rest of the regional economy. It also gives a fairly accurate indication of the value of transactions between the different sectors in 1985. From the transaction table it is evident that the bulk of economic activity in the region is aimed at servicing the primary sectors. Little or no inputs for agriculture are manufactured within the region. The bulk of the products produced in the region is also processed and consumed elsewhere. The gross geographical product (GGP) for the region is R43.67 million. The total output of Irrigation agriculture is R20.14 million and the value added is R5.82 million. Taken together, agriculture contributes 25 per cent of the GGP. Irrigation agriculture occupies only 1 per cent of the area of the south-western Orange Free State, but provides 40 per cent of the total output of agriculture.

\section{DETERMINATION OP THE ECONOMIC IMPACT OF IRRIGATION AGRICULTURE IN THE SOUTH-WESTERN ORANGE FREE STATE}

The format for determining multipliers in this study is the same as that used by Powell et al (1985) and Booth et al (1981). For the calculation of the different multipliers a matrix of direct coefficients and a Leontief inverse matrix must be determined from the transaction table through mathematical manipulation. Detailed procedures for this manipulation can be found in Powell et al (1985). 


\section{5.l Output multipliers}

The initial impact, first-round effects, secondary effects and consumptioninduced effects can be combined in a total output multiplier. Table 3 shows the different effects and the total output multiplier for irrigation agriculture.

The total output multiplier for irrigation agriculture is 1.7012 (Table 3), which means that for every R1 of production or output in irrigation agriculture, an additional output of 70.12 cents is generated by the intermediate sectors and households within the region. It also means that production of R1 in irrigation agriculture yields a total effect of R1.7012 on total production in the region. In this regard it is important to note that the output multiplier for irrigation agriculture is among the highest of all the sectors in the south-western Orange Free State (See also Table 4).

The indirect effect in terms of output is R0.7012 (Table 3). Table 4 shows which sectors benefit most from this indirect effect. From Table 4 it is evident that the majority of the indirect effects go to the trading sector. 
Table 2 - The final input-output table for the south-western Orange Free State

\begin{tabular}{|c|c|c|c|c|c|c|c|c|c|c|c|c|c|c|c|c|c|c|c|c|c|}
\hline No Sector & $\begin{array}{l}\text { Agri- } \\
\text { culture }\end{array}$ & $\begin{array}{l}\text { Irri- } \\
\text { gation }\end{array}$ & $\begin{array}{l}\text { Mi- } \\
\text { ning }\end{array}$ & Food & $\begin{array}{l}\text { Li- } \\
\text { quor }\end{array}$ & $\begin{array}{l}\text { Tex- } \\
\text { tile }\end{array}$ & $\begin{array}{l}\text { Non } \\
\text { metal } \\
\text { mine- } \\
\text { rals }\end{array}$ & $\begin{array}{l}\text { Elec- } \\
\text { tri- } \\
\text { city }\end{array}$ & $\begin{array}{l}\text { Con- } \\
\text { struc- } \\
\text { tion }\end{array}$ & Trade & $\begin{array}{l}\text { Trans- } \\
\text { port }\end{array}$ & Finance & $\begin{array}{l}\text { Ser- } \\
\text { vices }\end{array}$ & $\begin{array}{l}\text { Inter. } \\
\text { de- } \\
\text { mand }\end{array}$ & $\begin{array}{l}\text { Con- } \\
\text { sump } \\
\text {-tion }\end{array}$ & $\begin{array}{l}\text { Govern- } \\
\text { ment }\end{array}$ & Capital & Stocks & Exports & $\begin{array}{l}\text { Final } \\
\text { demand }\end{array}$ & $\begin{array}{l}\text { Total } \\
\text { output }\end{array}$ \\
\hline 1 Agriculture & 1.82 & 0.25 & 0.00 & 1.67 & 0.00 & 0.00 & 0.00 & 0.00 & 0.00 & 2.20 & 0.00 & 0.00 & 0.00 & 5.94 & 0.30 & 0.30 & 0.00 & 0.97 & 22.32 & 23.89 & 29.83 \\
\hline 2 Irrigation & 1.47 & 0.00 & 0.00 & 0.19 & 0.18 & 1.40 & 0,00 & 0.00 & 0.00 & 5.19 & 0.00 & 0.00 & 0.00 & 8.43 & 0.20 & 1.60 & 0.00 & 0.00 & 9.91 & 11.71 & 20.14 \\
\hline 3 Mining & 0.00 & 0.00 & 0.00 & 0.00 & 0,00 & 0,00 & 0,00 & 0.00 & 0.00 & 0.00 & 0.00 & 0.00 & 0.00 & 0.00 & 0.00 & 0.00 & 0.00 & 0.00 & 0.22 & 0.22 & 0.22 \\
\hline 4 Food & 0.39 & 0.00 & 0.00 & 0.24 & 0.00 & 0,00 & 0.00 & 0.00 & 030 & 032 & 0.00 & 0.00 & 0.00 & 0.95 & 2.95 & 0.13 & 0.00 & 0.04 & 0.26 & 3.38 & 4.33 \\
\hline 5 Liquor & 0.00 & 0.00 & 0.00 & 0.00 & 0.00 & 0.00 & 0.00 & 030 & 0.00 & 033 & 0.00 & 0.00 & 0.00 & 0.03 & 0.30 & 0.00 & 0.00 & 0.02 & 0.87 & 1.19 & 1.22 \\
\hline 6 Textiles & 0.00 & 0.00 & 0.00 & 0.00 & 0.00 & 0.00 & 0.00 & 030 & 0,00 & 0.00 & 0.00 & 0.00 & 0.00 & 0.00 & 0.05 & 0.14 & 0.00 & 0.07 & 6.28 & 6.54 & 6.54 \\
\hline $\begin{array}{l}7 \text { Non-metal } \\
\text { minerals }\end{array}$ & 0.10 & 0.10 & 0.00 & 0.00 & 0.00 & 0,00 & 0.00 & 030 & 0,06 & 0.03 & 0.00 & 0.00 & 0.00 & 0.29 & 0.04 & 0.00 & 0.00 & 0.00 & 0.10 & 0.14 & 0.43 \\
\hline 8 Electricity & 1.08 & 1.17 & 0.00 & 0.04 & 0.04 & 0.16 & 0.04 & 2.74 & 0.02 & 0.64 & 0.10 & 0,03 & 0.03 & 6.10 & 9.28 & 0.44 & 0,00 & 0.06 & 0,00 & 9.78 & 15.88 \\
\hline 9Construction & 0.25 & 0.00 & 0.01 & 0.00 & 0.00 & 0.00 & 0.00 & 0.06 & 1.74 & 0.12 & 0.02 & 0.02 & 0.00 & 2.21 & 0.00 & 0.29 & 12.62 & 0.01 & 0.09 & 13.01 & 15.22 \\
\hline 10 Trade & 7.49 & 5.01 & 0.00 & 0.02 & 0.05 & 0.10 & 0.01 & 0.04 & 0.10 & 0.61 & 0.65 & 0.05 & 0.05 & 14.18 & 8.30 & 0.45 & 0.16 & 0.05 & 7.19 & 16.15 & 30.33 \\
\hline 11 Transport & 1.32 & 1.39 & 0.00 & 0.04 & 0.00 & 0.10 & 0.01 & 0.04 & 0.07 & 0,64 & 0.25 & 0.15 & 0.16 & 4.17 & 1.97 & 0.43 & 0.00 & 0.02 & 2.26 & 4.68 & 8.85 \\
\hline 12 Finance & 2.20 & 0.49 & 0.00 & 0.06 & 0.04 & 0.14 & 0.01 & 0.03 & 0.25 & 0.84 & 0.03 & 0.68 & 0.13 & 4.90 & 2.87 & 0.52 & 0.07 & 0.02 & 0.48 & 3.96 & 8.86 \\
\hline 13 Services & 0.11 & 0.95 & 0.02 & 0.10 & 0.04 & 0.15 & 0.02 & 0.24 & 0.26 & 0.17 & 0.03 & 0.02 & 0.02 & 2.13 & 2.26 & -1.47 & 0.00 & 0.01 & 0.06 & 0.86 & 2.99 \\
\hline 14 Inter, inputs & 16.23 & 9.36 & 0.03 & 2.36 & 0.35 & 2.05 & 0.09 & 3.15 & 2.50 & 10.79 & 1.08 & 0.95 & 0.39 & 49.33 & 28.52 & 2.83 & 12.85 & 1.27 & 50.04 & 95.51 & 144.84 \\
\hline 15Remuneration & 2.02 & 1.39 & 0.04 & 0.25 & 0.14 & 0.19 & 0.02 & 1.39 & 3.76 & 2.53 & 2.01 & 2.51 & 0.30 & 17.05 & 1.53 & 11.98 & 0.00 & 0.00 & 0,00 & 13.51 & 30.56 \\
\hline 18 Surplus & 3.28 & 4.43 & 0.09 & 0.26 & 0.14 & 0.45 & 0.18 & 6.36 & 0.87 & 5.13 & 2.86 & 1.69 & 0.88 & 26.62 & 0.00 & 0.87 & 0.00 & 0.00 & 0,00 & 0.87 & 27.49 \\
\hline 17 Indirect tax & 0.48 & 0.19 & 0.00 & 0.07 & 0.00 & 0.06 & 0.05 & 0.29 & 0.58 & 0.17 & 0.12 & 0.37 & 0.00 & 2.38 & 17.68 & 0.00 & 0.00 & 0.00 & 0,00 & 17.68 & 20.06 \\
\hline 18 Imports & 7.65 & 4.87 & 0.05 & 1.33 & 0.63 & 3.38 & 0.09 & 4.19 & 7.51 & 11.49 & 2.54 & 3.99 & 1.42 & 49.14 & 77.68 & 8.24 & 0.63 & 0.56 & 0,00 & 87.11 & 136.25 \\
\hline 19 Subtotal & 29.66 & 20.24 & 0.21 & 4.27 & 1.26 & 6.13 & 0.43 & 15.38 & 15.22 & 30.11 & 8.61 & 9.51 & 2.99 & 144.52 & 125.41 & 23.92 & 13.48 & 1.83 & 50.04 & 214.68 & 359.20 \\
\hline 20 Net transfers & 0.17 & -0.10 & 0.01 & 0.06 & $-0,04$ & 0.41 & 0.00 & 0.00 & 0.00 & 0.22 & 0.24 & -0.65 & 0.00 & 0.32 & 0.00 & 0.00 & 0.00 & 0.00 & 0.00 & 0.00 & 0.32 \\
\hline 21 Total inputs & 29.83 & 20.14 & 0.22 & 4.33 & 1.22 & 6.54 & 0.43 & 15.38 & 15.22 & 30.33 & 8.85 & 8.86 & 2.99 & 144.84 & 125.41 & 23.92 & 13.48 & 1.83 & 50.04 & 214.68 & 359.52 \\
\hline
\end{tabular}


Table 3- Output multipliers for irrigation agriculture (rand)

Output multiplier

Value (R)

1. Direct or initial impact

1.0000

2. First-round effects

0.4647

3. Secondary effects

0.1878

4. Consumption-induced effects

0.0487

Total (output multiplier)

1.7012

5. Indirect effects

0.7012

Table 4 - Sectoral distribution of indirect effects

\begin{tabular}{lcc}
\hline Sector & $\begin{array}{c}\text { Indirect } \\
\text { effects } \\
\text { (cents) }\end{array}$ & $\begin{array}{c}\text { Percentage } \\
\text { of total } \\
(\%)\end{array}$ \\
\hline 1. Rest of agriculture & 4.04 & $5.76 \%$ \\
2. Irrigation agriculture & 5.34 & $7.62 \%$ \\
3. Mining & 0.00 & $0.00 \%$ \\
4. Manufacturing: Food & 0.77 & $1.09 \%$ \\
5. Manufacturing: Liquor & 0.07 & $0.09 \%$ \\
6. Manufacturing: Textiles & 0.01 & $0.01 \%$ \\
7. Manufacturing: Non-metal minerals & 0.57 & $0.81 \%$ \\
8. Electricity & 9.98 & $14.23 \%$ \\
9. Construction & 0.25 & $0.35 \%$ \\
10. Trade & 29.66 & $42.29 \%$ \\
1. Transport and communication & 9.00 & $12.84 \%$ \\
12. Finance & 4.72 & $6.73 \%$ \\
13. Services & 5.71 & $8.14 \%$ \\
\hline Total & 70.12 & $100.00 \%$ \\
\hline
\end{tabular}

\subsection{Income multipliers}

Income multipliers measure the change in income that results from the initial change in output. The total income multiplier for irrigation agriculture is 15.3 cents. The initial impact is 6.9 cents and the indirect effects are equal to 8.4 cents.

\subsection{Employment multipliers}

The total employment multiplier for irrigation agriculture is 89.14. This means that for every R1 million output produced by irrigation agriculture, 89.64 persons are employed, of which 67.8 persons are employed in irrigation agriculture. The rest are employed in other sectors as a direct result of production in irrigation agriculture. 


\subsection{Summary of multipliers and the economic impact of irrigation development}

Table 5 shows output, income and employment multipliers for all sectors of the economy of the south-western Orange Free State.

Table 5 - Sectoral multipliers for the south-western Orange Free State, 1988

\begin{tabular}{lccc}
\hline \multicolumn{1}{c}{ Sector } & $\begin{array}{c}\text { Output per } \\
\text { unit output }\end{array}$ & $\begin{array}{c}\text { Income per } \\
\text { unit output }\end{array}$ & $\begin{array}{c}\text { Employment } \\
\text { per R1m } \\
\text { output } \\
\text { (persons) }\end{array}$ \\
\hline 1. Rest of agriculture & $\mathbf{( R )}$ & $\mathbf{( R )}$ & 151.38 \\
2. Irrigation agriculture & 1.8628 & 0.1727 & 89.64 \\
3. Mining & 1.7012 & 0.1530 & 79.80 \\
4. Manufacturing: Food & 1.2282 & 0.2087 & 90.39 \\
5. Manufacturing: Liquor & 1.9987 & 0.1541 & 47.01 \\
6. Manufacturing: Textile & 1.4770 & 0.1684 & 30.80 \\
7. Manufacturing: Non- & 1.5031 & 0.0832 & \\
$\quad$ metal minerals & 1.2869 & 0.0863 & 46.60 \\
8. Electricity & 1.2955 & 0.1555 & 21.99 \\
9. Construction & 1.2934 & 0.3019 & 76.78 \\
10. Trade & 1.6097 & 0.1501 & 51.01 \\
11. Transport and com- & & & \\
$\quad$ munication & 1.2545 & 0.2586 & 35.65 \\
12. Finance & 1.2283 & 0.3265 & 15.43 \\
13. Services & 1.2017 & 0.1374 & 48.04 \\
\hline
\end{tabular}

Table 6 - Total impact of irrigation agriculture in the south-western Orange Free State, 1988

\begin{tabular}{lccc}
\hline & Direct impact & Total impact & Indirect effects \\
\hline Output & $\mathrm{R} 20.14 \mathrm{~m}$ & $\mathrm{R} 34.26 \mathrm{~m}$ & $\mathrm{R} 14.12 \mathrm{~m}$ \\
Income & $\mathrm{R} 1.39 \mathrm{~m}$ & $\mathrm{R} 3.08 \mathrm{~m}$ & $\mathrm{R} 1.69 \mathrm{~m}$ \\
Employment & 1366 persons & 1806 persons & 440 persons \\
\hline
\end{tabular}

Table 7 - Total economic impact of irrigation agriculture and its associated industries in the south-western Orange Free State, 1988

\begin{tabular}{|l|c|c|c|c|}
\hline & $\begin{array}{c}\text { Direct } \\
\text { impact }\end{array}$ & $\begin{array}{c}\text { Total } \\
\text { impact }^{1)}\end{array}$ & $\begin{array}{c}\text { Forward } \\
\text { linkages }\end{array}$ & Total \\
\hline Output & $\mathrm{R} 20.14 \mathrm{~m}$ & $\mathrm{R} 34.26 \mathrm{~m}$ & $\mathrm{R} 3.12 \mathrm{~m}$ & $\mathrm{R} 37.38 \mathrm{~m}$ \\
\hline Income & $\mathrm{R} 1.39 \mathrm{~m}$ & $\mathrm{R} 3.08 \mathrm{~m}$ & $\mathrm{R} 0.19 \mathrm{~m}$ & $\mathrm{R} 3.27 \mathrm{~m}$ \\
\hline Employment & 1366 persons & 1806 persons & 47 persons & 1853 persons \\
\hline
\end{tabular}

\footnotetext{
1 Direct impact plus backward linkages
} 
The multipliers obtained in this study, especially for agriculture (irrigation and other) compare well with those reported in similar studies done elsewhere. The output multiplier is marginally lower than most of those determined by Powell et al (1985) in Australia, and Lamphear \& Rousler in Nebraska. It is, however, higher than that determined by Booth et al (1981) in Australia and Fullerton et al in Colorado. Multipliers obtained by Van Zyl \& Nel (1988) for South African agriculture as a whole and for the meat industry compare favourably with those for the rest of agriculture obtained in this study.

The total economic impact of irrigation agriculture is summarized in Table 6. However, to get a more complete picture, the forward linkages must also be taken into account. These are shown in Table 7.

Irrigation agriculture and its associated activities are responsible for a total output of R37.38 million, income of R3.27 million and employment of 1853 persons in the south-western Orange Free State.

\section{CONCLUSION}

Irrigation agriculture makes an important contribution towards the regional economy of the south-western Orange Free State through its forward and backward linkages. It is also clear that there exists a positive relationship between irrigation development and increased regional economic activity. The total impact of irrigation agriculture on the regional economy is larger than the direct impact. This is due to the multiplier effects that obtain via the backward and forward linkages. The indirect effects of irrigation agriculture in the south-western Orange Free State in 1985 were as follows:

$\begin{array}{ll}\text { - Output } & : \text { R17.24 million } \\ \text { - Income } & : \text { R1.88 million } \\ \text { - Employment } & : 478 \text { persons }\end{array}$

The results reported here must, however, be seen and interpreted against the background of the different assumptions of the analyses. These assumptions place restrictions on the accuracy and use of the multipliers. In this respect the assumptions of constant price ratios and of identical production methods and the assumption that no factors of production are reemployed, are of some importance. These assumptions influence the impact results in the case of external changes. However, because this study only evaluates the current impact and not the marginal impact, these necessary assumptions do not necessarily have a negative influence on the results.

No capital expenditures are indicated in the input-output model used in this study. The economic impact of capital expenditures was therefore not calculated. The total impact of irrigation agriculture is thus to some extent undervalued in this case. The employment of seasonal labour was also ignored. The impact of irrigation agriculture in terms of employment and household income was thus also to some extent undervalued. The use of the input-output technique does, however, lead to a slight over estimation of the multipliers in general (Faminow. 1989). These slight over- and underestimations could thus cancel each other out. 
Impact analysis in South African agriculture has been done by Van Zyl \& Nel (1988) and Tarr (1974) among others, but only on a national basis. This study probably represents the first empirical application of a regional input-output table on agriculture in South Africa.

Although this study sheds more light on the total impact of irrigation development in a regional context, the uniqueness of the area analysed means that the results are not generally applicable. However, this emphasizes the need for other studies in different areas and also serves as a motivation of why national analyses are insufficient when working in a regional context.

\section{BIBLIOGRAPHY}

ANDERSON, A W \& MANNING, T W. 1983. 'The use of input-output analysis in evaluating water resource development.' Canadian Journal of Agricultural Economics, Vol 31. no 1: 15-26.

BACK, W B, 1969. 'Estimating contributions of natural resource investments to objectives in regional economic development'. American Journal of Agricultural Economics, Vol 31, no 5, December.

BELL, C L G \& HAZELL, P B R. 1980. 'Measuring the indirect effects of an agricultural investment project on its surrounding region'. American Journal of Agricultural Economics, Vol 62, no 1, February.

BELL, C L G, HAZELL, P B R \& SLADE, R. 1982. Project evaluation in regional perspective. A World Bank Research Publication, Johns Hopkins University Press, London.

BONNER, E R \& VAHLE, V L, 1967. Technique for area planning: A manual for the construction and application of a simplified input-output table. Regional Economics Development Institute,

Pittsburgh, Pennsylvania.

BOOTH, J, BOUGHTON, W C, McDONALD, G T \& OSBORN, R C, 1981. A study of the irrigation industry in the Upper Condamine Basin. Institute of Applied Social Research. Griffith University. Queensland.

BROWN, R J, 1981. 'Simulating the impact of an irrigation project on a small regional economy'. Growth and Change, Vol 12, no 2, April.

BUTCHER, WR, 1974. 'The role of water resources in community development'. In Field, D R, Barron, J C \& Long. B F (eds). Water and community development: Social and economic perspectives. Ann Arbor Science Publishers. Ann Arbor, Michigan.

CARRUTHERS, I D. 1973. Impact and economics of community water supply: A study of rural water investment in Kenya. Agrarian Development Unit. Wye College. London.

CASTLE, E N, KELSO, M M, STEVENS, J B \& STOEVENER, H H, 1981. Natural resource economics. 1946-1975. In Martin, L R (ed). A survey of agricultural economics literature: Vol 3: Economics of welfare, rural development and natural resources in agriculture. $1940 \mathrm{~s}$ to 1970s. University of Minnesota Press, Minneapolis.

CENTRAL STATISTICAL SERVICES, 1987. Agricultural census 1965. Report No 06 - 01 - 22, Pretoria.

CICCHETTI, C J. SMITH, V K \& CARSON, J. 197S. An economic analysis of water resource investments and regional economic growth. Water resources research, Vol 11, no 1, February. COX,. P T, GROVER,. W \& SISKIN, B, 1971, 'Effects of water resources investment on economic growth. Water resources research. Vol 7. February. 
EDWARDS, C, 1981. 'The bases for regional growth'. In Martin, LR(ed) A survey of agricultural economics literature: Vol 3: Economics of welfare, rural development and natural resources in agriculture, 1940s to 1970s. University of Minnesota Press. Minneapolis.

EISEL, M L, SEINWILL, G D \& WHEELER, R M, 1982. Improved principles, standards and procedures for evaluating federal water projects'. Water resources research, Vol 18, no 2:203-210. FAMINOW, M. 1989. Speech delivered at a seminar on input-output analysis, Development Bank of Southern Africa, Halfway House, April 18.

FOURIE, J F. 1977. 'Inleidende notas oor ekonomiese basisteorie en inset-uitsetontledings'. Speech at ISEN on 19 April. Bloemfontein.

FULLERTON, H H., LEWIS, W C, ANDERSON, J L, KEITH., J E \& WILLIS, R. 1975. Regional development: An econometric study of the role of water development in effectuating population and Income changes. Utah State University, Logan, Utah.

GARDNER, B D \& HUFFAKER., R G. 1988. 'Cutting the losses from Federal Irrigation Water Subsidies'. Choices, Vol 3, no 4.

HAZELL, P B R \& NORTON, R D, 1986. Mathematical programming for economic analysts in agriculture. Macmillan, New York.

HEWINGS, G J D, 1985. Regional input-output analysis. Scientific Geography Series. Vol 6. Sage Publication Inc. Beverley Hills, California.

HEWINGS, G J D \& JENSEN, R C, 1986. 'Regional, inter-regional and multi-regional input-output analysis'. In Nykamp. R (ed) Handbook of regional and urban economics. Vol 1: Regional economics. North Holland. Amsterdam.

HOWE, C W, 1968. 'Water resources and regional economic growth in the United States 1950 -1960'. Southern Economic Journal. Vol 34. no 4: 477 - 500.

ISSERMAN, A M. 1980. 'Estimating export activity in a regional economy: A theoretical and empirical analysis of alternative methods'. International Regional Science Review, Vol 5, no 2: 155-184.

JOHNS, P M \& LEAT, P M K. 1987. The application of modified GRIT input-output procedures to rural development analysis in Grampian Region'. Journal of Agricultural Economics. Vol 38, no 2.

KAHN, R F, 1931. The relation of home investment to unemployment'. The Economic Journal. Vol 41: 179- 198.

LAMPHEAR, F C \& ROUSLER, T W, 1974. Impact analysts of irrigated agriculture on Nebraska's economy 1967-1970. The University of Nebraska. Lincoln.

LEISTRTTZ, F L \& MURDOCH., S H, 1981. The socioeconomic impact of resource development Methods for assessment. Westview Press, Boulder, Colorado.

LEWIS, W C., ANDERSEN, J C., FULLERTON, H H \& GARDNER., B D, 1973. Regional growth and water resources investment. DC Heath and Co, Lexington. Massachusetts.

LONG, RB, 1980. 'Primary and secondary impacts of a water resource development project'. Water Resources Bulletin, Vol 16, no 6, December.

MARTIN, W E, 1979. 'Returns to public irrigation development and the concomitant cost of community programs'. American Journal of Agricultural Economics, Vol 61, no 5, December. MAZUERA, O E. 1969. Economic impact of irrigation development: Sugar Creek Watershed, Oklahoma. PhD, Oklahoma State University, Stillwater.

McCULLICK, J J, 1970. The economic impact irrigation development on selected south west Kansas counties: An input-output approach. PhD, Kansas State University, Manhattan, Kansas. MENTZAS, G N, CAPROS, P, \& SAMOULIOIS, IC, 1987. 'Modelling the regional impacts of energy development: A survey'. Socio-Economic Planning Sciences. Vol 21, no 3: 151 -158. MIRRILEES, R I. 1984. A short-cut technique for regional input-output modelling in South Africa. Occasional Paper No 2. Institute for Futures Research, University of Stellenbosch. MOHR, I T, \& VAN SEVENTER, D E N, 1988. The compilation and application of provisional 
regional input-output tables for Southern Africa. Development Southern Africa, Vol 5, no 4, November.

MORRISON, WI \& SMITH, P, 1974. Nonsurvey input-output techniques at the small area level: An evaluation'. Journal of Regional Science. Vol 14, no 1.

MULES, T J, 1983. 'Input-output analysis in Australia: An agricultural perspective'. Review of Marketing and Agricultural Economics, Vol 51, no 1: 9-30.

O'CONNOR, R \& HENRY, E W, 1975. Input-output analysis and its applications. Charles Griffin \& Co, London.

OLIVIER, H. 1972. The impact of irrigation on regional economic growth'. In Olivier. H. Irrigation and water resources engineering. Edward Arnold, London.

OOSTHUIZEN, N J, VAN DER MERWE, R B \& V1LJOEN, M F. 1987. 'Die sosio-ekonomiese impak van besproeiingsontwikkeling'. Unpublished draft report to the Department of Water Affairs. Institute for Social and Economic Research (ISER), University of the Orange Free State, Bloemfontein.

PLEETER, S. 1980. 'Methodologies of economic impact analysis: An overview'. In Pleeter, S (ed). Economic impact analysts: Methodology and applications. Martinus Nijhof Publishing, Boston. POWELL, R A \& MANDEVTLLE, T D, 1978. 'Analysis of sector interactions and stability in a rural region of NSW'. Economic Record. Vol 54: 239 - 255.

POWELL, R A, JENSEN, R C \& GIBSON, A L, 1985. The economic impact of irrigated agriculture in NSW. Department of Agricultural Economics and Business Management, University of New England. Armidale, NSW, Australia.

RICHARDSON, H W, 1972. Input-output and regional economics. Weldenfeld \& Nicholson. London.

RICHARDSON, H W, 1973. Regional growth theory. Macmillan Press. London.

ROMANOFF, E, 1974. 'The economic base model: A very special case of input-output analysis'.

Journal of Regional Sciences (ed) Vol 14: 121 -130.

ROUKENS DE LANGE, A, 1985. 'Preparation of regional input-output tables: A re-evaluation'. Unpublished manuscript. Institute for Futures Research, University of Stellenbosch. April.

SCHAFFER, W A. 1976. On the use of Input-output models for regional planning. Studies In applied regional science. Vol 1, Martinus Nijhof, Leiden.

SCHAFFER, W A, 1980. 'The role of input-output models in regional impact analysis'. In Pleeter, S (ed) Economic impact analysts: Methodology and applications. Martinus Nijhof Publishing. Boston.

SMITH, C A \& JENSEN, R C, 1984. A system for the generation of a small economy inputoutput table. Papers of the Eighth Meeting of the Australian and New Zealand Section of the Regional Science Association.

STOEVENER., H H \& KRAVNICK, R G, 1979. 'On augmenting community economic performance by new or continuing irrigation developments'. American Journal of Agricultural Economics. Vol 61. no 5, December.

TARR, M. 1974. 'An input-output study of agricultural labour in South Africa'. Unpublished MSc (Agric) thesis, University of Natal, Pietermaritzburg.

TIEBOUT, C M, 1962. The community economic base study. Supplementary Report No 16, Committee for Economic Development New York.

UNDERWOOD McLELLAN LTD, 1984. 'The economic impact of irrigation development in Alberta'. Unpublished report to the Alberta Irrigation Projects Association, Lethhridge, Alberta.

VAN ZYL, J \& NEL, H G J. 1988. 'Die rol van die mieliebedryf in die Suid-Afrikaanse ekonomie'. Agrekon, Vol 27. no 2. July.

WALKER, A L et al 1966. The economic significance of Columbia Basin project development. US Bureau of Reclamation, Department of the Interior.

WEST, G R., WILKINSON, J T \& JENSEN, R C. 1979. Generation of regional input-output tables 
for the state and regions of South Australia. Department of Economics. University of Queensland.

WEST, G R, WILKINSON, J T \& JENSEN, R C. 1980. Generation of regional input-output tables for the Northern Territory. Report to the Chief Minister of the Northern Territory. Department of Economics, University of Queensland.

WHITTLESEY, N K, GIBBS, K C \& BUTCHER, W K, 1978. 'Social overhead capital costs of irrigation development in Washington State'. Water Resources Bulletin. Vol 14, no 3. June.

YOUNG, R A. 1978. Economic analysis and federal irrigation policy: A reappraisal. Western Journal of Agricultural Economics, December. 